\title{
Biology and Yield of Rocket (Eruca sativa Mill.) under Field Conditions of the Czech Republic (Central Europe)
}

\author{
Ivana DOLEŽALOVÁ ${ }^{1 *}$, Martin DUCHOSLAV ${ }^{2}$, Karel DUŠEK ${ }^{1}$ \\ ${ }^{1}$ Department of Genetic Resources for Vegetables, Medicinal and Special Plants, Centre of Applied Research \\ of Vegetables and Special Crops of the Crop Research Institute in Olomouc, Šlechtitelu 29, 78371 Olomouc, \\ Czech Republic; dolezalova@genobanka.cz (*correspondingauthor); dusek@genobanka.cz \\ ${ }^{2}$ Plant Biosystematics and Ecology Research Group, Department of Botany, Faculty of Science, Palacky University \\ in Olomouc, Šlechtiteli 11, 78371 Olomouc, Czech Republic; martin.duchoslav@upol.cz
}

\begin{abstract}
Five rocket (Eruca sativa Mill.) varieties and accessions were cultivated under field conditions in the Czech Republic (Central Europe) and subsequently studied for variation in morphology and yield. Two cultivation techniques (treatments) were tested during the growing seasons in 2010 and 2011: directly sown seeds in the field and plantlets cultivated in a glasshouse and later transplanted to the field. There were analysed four morphological parameters of the leaf rosette (leaf shape in outline, leaf margin, leaf apex and leaf colour), marketable yield, nonmarketable parts, and rosette radius. Plants from plantlets transplanted to the field in spring terms (April) yielded a substantially higher marketable yield and had a higher rosette radius in contrast to plants from directly sown seeds. Conversely, for the summer terms of sowing (late August, September) the direct sowing technique produced higher marketable yield in comparison with plantlets treatment. Plants cultivated from directly sowed seeds reached a marketable yield on average from 15 to 60 g per plant while transplanted plants produced on average from 10 to $49 \mathrm{~g}$ per plant. It is evident that cultivation of rocket under field conditions of the Czech Republic is possible and provides, when using the appropriate sowing term, more or less stable yields of marketable parts. Details on variation in yield parameters of individual varieties and accessions are presented.
\end{abstract}

Keywords: cultivation technique, harvest, leaf morphology, leaf rosette, rocket salad

\section{Introduction}

Rocket (Eruca sativa Mill.) is an annual species belonging to the mustard family (Brassicaceae). Common names include salad rocket, garden rocket, arugula (English); salatrauke (German); oruga, oruga común, eruca (Spanish), roquette (French), and rucola (Italian) (Bianco, 1995). Rocket is a general name for plants which form rosette of brightly green divided leaves with a specific flavour. Similarly to other Brassicas, Eruca sativa contains glucosides such as allyl sulphocyanate, while its seed oil contains erucid acid (Nuez and Hernández Bermejo, 1994).

The genus Eruca L. includes a single species Eruca vesicaria (L.) Cav. with the three infraspecific taxa: subsp. sativa (Miller) Thell., subsp. vesicaria and subsp. pinnatifida (Desf.) Emberger et Maire (Pignone and Gómez-Campo, 2011). E. vesicaria subsp. sativa (Miller) Thell. is the only taxon with a rather wide circum-Mediterranean distribution and has been further introduced into other countries and continents. It is still frequently referred under simplified synonym E. sativa Mill. (Pignone and Gómez-Campo, 2011).

Eruca sativa has been known since antiquity and has widely been consumed in various Mediterranean countries for the spicy-pungent flavour of the leaves (Padulosi,
1995; Padulosi and Pignone, 1997). Rocket is eaten as a vegetable (leaves) and as a spice (leaves, seeds, flowers) (Nuez and Hernández Bermejo, 1994). It is consumed as a raw green, as a part of salad mixes, as a cooked green, and is now very popular as a pizza topping (Padulosi, 1995; Padulosi and Pignone, 1997). Rocket is used in many ways other than a food. On the Indian subcontinent, special ecotypes of $E$. sativa are cultivated for seed production and subsequent oil extraction (Bhandari and Chandel, 1997). Rocket is believed to have aphrodisiac properties (Padulosi, 1995). It contains glucosides, mineral salts and vitamin $\mathrm{C}$ and is therefore considered to be an excellent stomachic, stimulant, and is also used as a diuretic and antiscorbutic (Nuez and Hernández Bermejo, 1994). Recent studies showed that an extract from rocket possess antisecretory, cyto-protective and anti-ulcer activities (Alqasoumi et al., 2009).

Rocket is traditionally grown in Italy, Portugal, Egypt, and Turkey (Bianco and Boari, 1997; Mohamedien, 1995; Pimpini and Enzo, 1997; Silva Dias, 1997; Tuzel, 1995), it has also been successfully investigated as a new crop for Indiana and US Midwest (Morales and Janick 2002; USDA, NRCS 2012), where it can be cultivated in open field and protected areas. In the past years rocket has increasingly become popular also in the Central Europe. It 
was introduced on the market as a so-called " $4^{\text {th }}$ generation" vegetable which is marketed after cleaning, leaf cutting and packaging into plastic bags to keep it fresh for a longer time-life (Padulosi, 1995). Currently, the studies on the quality and quantity of rocket yield were conducted in Poland (Francke, 2011; Nurzyńska-Wierdak, 2006, 2009; Nurzyńska-Wierdak, et al., 2012 a,b), however these studies were done under glasshouse conditions with plants cultivated in pots. Only short notes on experimental rocket cultivation as an intercrop and for seed production under field conditions of the Czech Republic have been published (Hermuth et al., 2001; Moudrý and Strašil, 1999; Šimon and Strašil, 1999). Nowadays, rocket is available in Czech supermarkets from Dutch production alone as a green or as a part of salad mixes. Despite of its high nutritional value rocket is still underestimated as vegetable in the Central Europe.

Our study was carried out to test the possibility of rocket cultivation under the ecological conditions of the Czech Republic (Central Europe), to characterize the crop for agrobotanical traits, and subsequently to offer this neglected vegetable to a broad public. The aims of this study were: (i) to summarize the most recent data on the biology and yield parameters of rocket cultivated under the conditions of the Czech Republic, (ii) to establish the most appropriate term of sowing and cultivation technique, and (iii) to select the most yielding genotype from the available stock of varieties.

\section{Materials and methods}

\section{Plant material and cultivation}

A set of five varieties and accessions was cultivated, and subsequently studied for variation in morphology and yield. Varieties of whose seed is readily available in the Czech market originated from Semo Ltd., Smržice and from Seva-Seed Ltd., Valtice. Two rocket accessions have been maintained as the plant genetic resources at Oseva Pro Ltd., Research Institute of Oilseed Crops, Opava. The passport data of the two accessions is documented in the Plant Genetic Resources Documentation System of the Czech Republic (EVIGEZ) (http://genbank.vurv.cz/genetic/resources/) and in the International Minor Leafy Vegetables Database operated by the Leibniz Institute of Plant Genetics and Crop Plant Research (IPK) in Germany (http://documents.plant.wur.nl/cgn/pgr/minorlv/). Information on the plant material is summarized in Tab. 1.

Tab. 1. List of rocket varieties and accessions used in the study
The research was carried out in the experimental field of the Crop Research Institute, Department of Genetic Resources for Vegetables, Medicinal and Special Plants, Olomouc. Yield parameters were studied during two growing seasons in the years 2010 and 2011. Two cultivation techniques (treatments) were tested: direct sowing of seeds in the field, and plantlets cultivated in a glasshouse and later transplanted to the field. Seeds for both cultivation techniques were always sown at the same time. The direct seeding treatment was performed as follows. Rocket seeds (seed sowing treatment) were sown directly in the field in furrows $70 \mathrm{~cm}$ long at a distance of $20 \mathrm{~cm}$. Threeweek old plantlets were singled to 8 plants per furrow. Each variety (accession) was seeded in two randomly selected plots consisting of eight furrows. Rocket plantlets (plantlet treatment) were firstly cultivated in the glasshouse at ambient temperature with natural lighting four to five weeks. At the stage of four adult leaves were transplanted to the field. Each variety (accession) was planted to two randomly selected plots each of eight furrows $70 \mathrm{~cm}$ long at a distance of $20 \mathrm{~cm}$ with 8 plants per furrow.

There were planned to test spring and summer terms of cultivation in two consecutive years but weather course within respective years did not allow beginning of field sowing/cultivation in the identical terms. Rocket seeds were sown in two spring (April 23 $3^{\text {rd }}$, June $8^{\text {th }}$ ) and two summer terms (August $23^{\text {rd }}$, September $13^{\text {th }}$ ) in the year 2010, and in three spring (April $11^{\text {th }}$, April $21^{\text {st }}$, May $2^{\text {nd }}$ ) and two summer terms (August 17 $7^{\text {th }}$, August 26 $6^{\text {th }}$ ) in 2011. Leaves of basal rosettes were harvested over six to eleven weeks at the stage when the plants possessed eight to ten fully developed adult leaves. From 19 to 51 plants from each variety (accession) per plot, depending on the number of survived plants were assessed.

\section{Morphological characterization and yield parameters}

Rocket plants were morphologically characterized following to IPGRI Descriptor list for rocket (http:// www.ecpgr.cgiar.org/fileadmin/www.ecpgr.cgiar.org/ NW_and_WG_UPLOADS/LeafyVeg_misc/Eruca_descriptor_list.pdf). The following parameters of leaf rosette were evaluated: leaf shape and margin, shape of apex and leaf colour. The leaf apex shape feature was added for precise characterization of leaf morphology because of the absence of this character in the IPGRI Descriptor list. Also rosette radius, marketable yield per plant (healthy, fully developed, brightly coloured leaves) and weight of nonmarketable leaf parts per plant were assessed.

\begin{tabular}{|c|c|c|c|}
\hline Variety/ Accession & Taxon & EVIGEZ & Origin \\
\hline A & Eruca sativa & & Semo Ltd., Smržice \\
\hline $\mathrm{C}$ & Eruca vesicaria subsp. sativa & & Seva-Seed Ltd., Valtice \\
\hline $\mathrm{D}$ & Eruca vesicaria subsp. sativa & & Seva-Seed Ltd., Valtice \\
\hline $\mathrm{E}$ & Eruca sativa Mill. & 1501200001 & Yugoslavia \\
\hline $\mathrm{F}$ & Eruca sativa Mill. & $15 \mathrm{O} 1200002$ & United Kingdom \\
\hline
\end{tabular}


532

Temperature, precipitation and soil type

Climate of Olomouc is warm, with average yearly temperature of $8.7^{\circ} \mathrm{C}$ and mean annual precipitation $547 \mathrm{~mm}$. Precipitation shows a typical continental annual course with a strong summer maximum in July $(83.3 \mathrm{~mm})$ and winter minimum in February $(23.7 \mathrm{~mm}$ ) (averages 19462009, Olomouc meteorological station). The course of the weather during the growing seasons in 2010 and 2011 was measured at a meteorological station near the experimental field. Basic meteorological data are shown in Tab. 2. The experimental field is located on alluvial sediments. E. sativa plants were grown on loam and sandy-loam soil. The plants were watered as the need arose. Supplementary fertilization was not applied.

\section{Data analysis}

The following variables were analysed: (i) marketable yield per plant ('marketable yield'), (ii) weight of non-marketable leaf parts per plant ('non-marketable parts'), and (iii) rosette radius. Common descriptive statistics were calculated and statistical tests carried out using the Statistica 10 software (Statsoft Inc.). Data were analysed using tree-way ANOVA with cultivation technique (seed sowing vs. transplanted plantlets), date of sowing and variety (accession) as fixed, crossed factors. Each year was analysed separately. Two dates of sowing/harvest were used in the 2010 experiment. Three of four dates of sowing/ harvest were analysed in the 2011 experiment due to the absence of leaf rosettes in samples from the direct sowing treatment harvested of June $28^{\text {th }}$ of 2011 . For comparison of means after significant results of ANOVA, the multiple comparisons Tukey test was used (Zar, 1996).

\section{Results}

In the trials, running for two years, emergence of rocket plantlets takes place within 6-9 days. Basic data on morphological characteristics in individual rocket varieties (accessions) are summarized in Tab. 3. Variety A and accession $\mathrm{F}$ showed morphological similarity, while variety $D$ was different from the others for characters evaluated.

In 2010, only two autumn harvests (October $14^{\text {th }}$ and December $1^{\text {st }}$ ) of basal rosettes from the summer terms of sowing were realized. Plants from the first spring sowing term were decimated by a long period of rainfalls, and plants from the second spring term flowered very early and they did not form leaf rosettes at all. Results of the 2010 experiment showed significant effect of cultivation technique, sowing date and the interaction cultivation technique $\times$ sowing date on the marketable yield, rosette radius and weight of non-marketable parts (Tab. 4). Effect of variety (accession) was non-significant, except for rosette radius. All other interactions were non-significant (Tab. 4). Marketable yield per plant, rosette radius and weight of non-marketable parts were all significantly higher in plants from the direct seed sowing treatment for both sowing dates, followed by lower values in plants from the transplanted plantlets treatment for earlier and late sowing dates (Fig. 1). The direct seed sowing treatment always produced proportionally more non-marketable parts (> than

Tab. 2. Sum of precipitation and mean temperatures during the growing seasons in the years 2010 and 2011 measured by the meteorological station in the proximity of the experimental field (Olomouc - Holice, Czech Republic)

\begin{tabular}{ccccc}
\hline & \multicolumn{2}{c}{ Precipitation $($ sum mm $)$} & \multicolumn{2}{c}{ Mean temperature $\left({ }^{\circ} \mathrm{C}\right)$} \\
\hline Month/ Year & 2010 & 2011 & 2010 & 2011 \\
\hline April & 49 & 71 & 9.8 & 12.1 \\
\hline May & 164 & 59 & 13.3 & 14.8 \\
\hline June & 45 & 87 & 21.6 & 18.7 \\
\hline July & 118 & 111 & 18.9 & 18.3 \\
\hline August & 106 & 70 & 13.2 & 19.9 \\
\hline September & 68 & 16 & 7.1 & 9.1 \\
\hline October & 6 & 26 & 6.7 & 2.5 \\
\hline November & 48 & 1 & - & - \\
\hline Total precipitation $(\mathrm{mm})$ & 602 & 440 & 8.7 & 9.8 \\
\hline Mean annual & - & - & & \\
temperature $\left({ }^{\circ} \mathrm{C}\right)$ & & & & \\
\hline
\end{tabular}

Tab. 3. Morphological characteristic of E. sativa varieties and accessions used in the study

\begin{tabular}{ccccc}
\hline Variety/ Accession & Leaf shape in outline & Leaf margin & Leaf apex & Leaf colour \\
\hline A & Obovate & Nearly entire to pinnatisect & Subacute to rounded & Green \\
C & Spathulate & Pinnatisect & Rounded & Green \\
D & Oblong & Pinnatisect & Acute & Light green \\
E & Spathulate & Nearly entire to & Subacute to rounded & Green \\
F & Obovate & Nearly entire to pinnatisect & Subacute to rounded & Green \\
\hline
\end{tabular}


$1 / 2$ of marketable parts) than the transplanted plantlets treatment (< than $1 / 3$ of marketable parts), irrespective of harvest date. Concerning variety (accession), only accession E showed a significantly larger rosette radius than the others (Tab. 4, Fig. 2).

Three spring and summer (June $8^{\text {th }}$, June $22^{\text {th }}$ and June $28^{\text {th }}$ ) and two autumn harvests (October $25^{\text {th }}$ and November $\left.8^{\text {th }}\right)$ were carried out in the year 2011. However, plants of the accession $\mathrm{E}$ from the harvest of June $22^{\text {th }}, 2011$ and all varieties (accessions) from the harvest of June $28^{\text {th }}, 2011$ originated from directly sown seeds were not evaluated. Moreover, plants from the harvest of October $25^{\text {th }} 2011$ were not assessed either. The reason was that they did not form tender leaf rosettes, leaves were thick and rigid, and possessed a high fraction of sclerenchymatic fibres. Results of the 2011 experiment showed significant effect of cultivation technique, sowing date and the interaction cultivation technique $\times$ sowing date on the marketable yield,
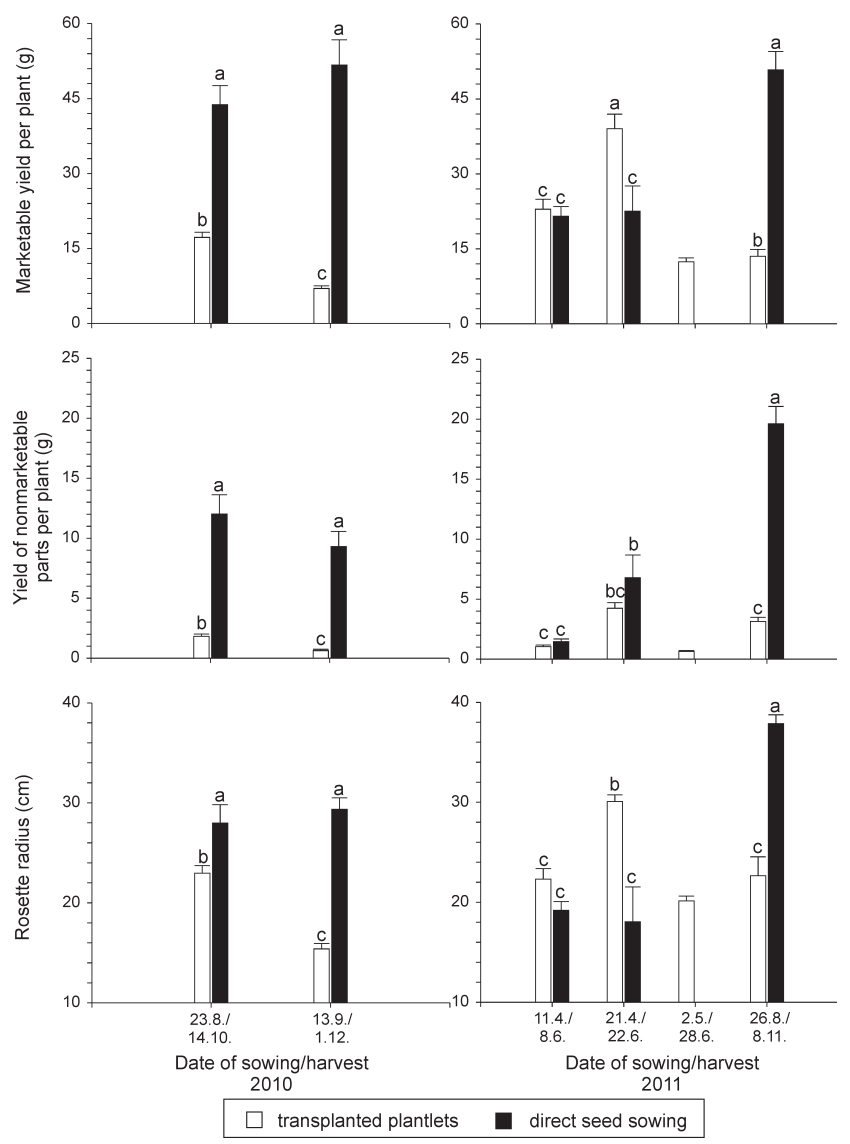

Fig. 1. Mean $(+1$ standard error) of marketable yield of leaves per plant, weight of nonmarketable parts per plant and rosette radius for two cultivation techniques (transplanted plantlets, direct seed sowing) in various dates of sowing/harvest in the 2010 and 2011 experiments. Statistically homogeneous groups ( $p$ > 0.05 ) are indicated by the same letter, separately for each variable and experiment. The third date of sowing/harvest (2.5./28.6.) were not statistically treated due to absence of data for direct seed sowing treatment rosette radius and weight of non-marketable parts (Tab. 4). Effect of variety (accession) was non-significant, except for marketable yield, where also the interaction variety $x$ sowing date were significant. All other interactions were non-significant (Tab. 4). Concerning marketable yield and rosette radius, the highest mean values were found for the last harvest date in sowing treatment followed by the second harvest date in the transplanted plantlets treatment. Values of marketable yield per plant and rosette radius were significantly smaller in other harvest dates, irrespective of treatment. Weight of nonmarketable parts per plant was also the highest in the last harvest date in sowing treatment, followed by lower values in the second harvest date and apparently low values in the other harvest dates, irrespective of treatment (Fig. 1). Concerning the effect of variety (accession), variety $\mathrm{C}$ showed a higher marketable yield than accession $\mathrm{E}$ for the first two harvest dates, but the opposite was true for the last date(s) (Fig. 3).

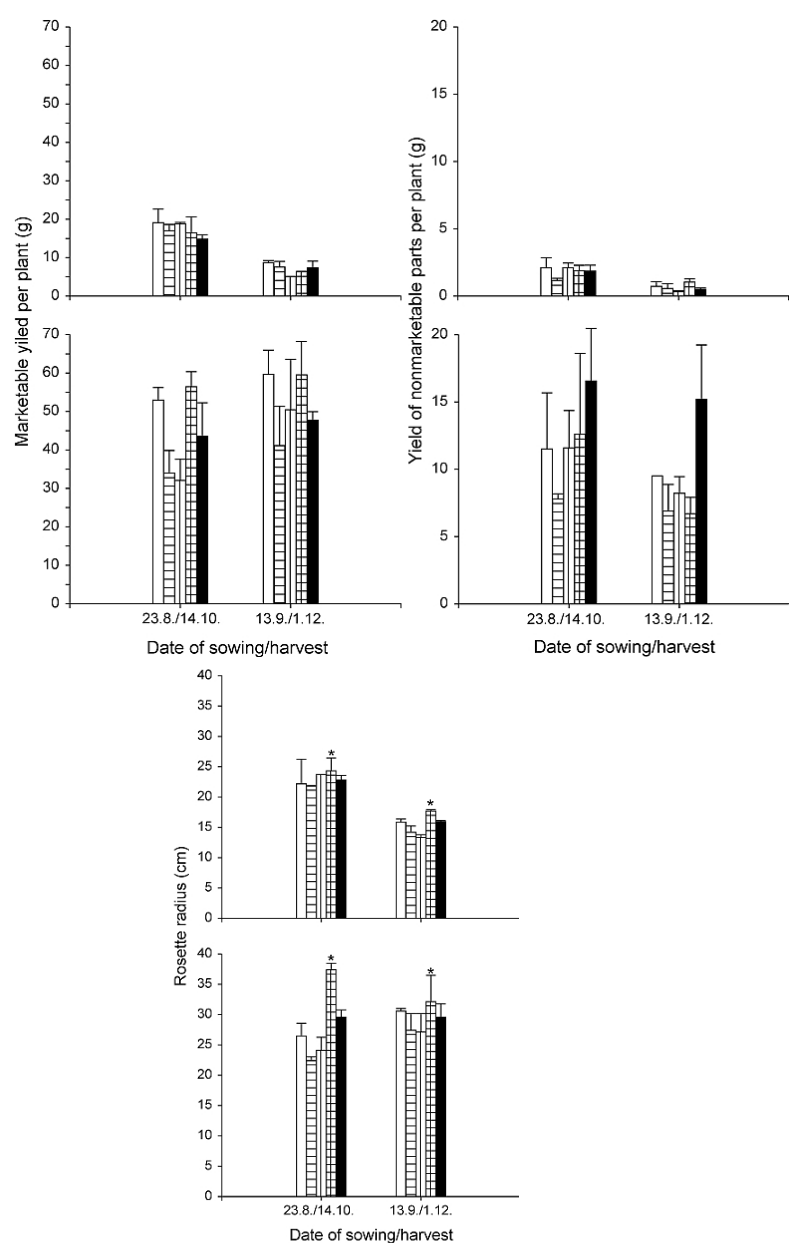

Fig. 2. Mean (+ 1 standard error) of marketable yield of leaves per plant, weight of nonmarketable parts per plant and rosette radius per variety (accession) (A, C, D, E, F from left to right) for various dates of sowing/harvest and cultivation technique in the 2010 experiment. Asterisks represent significantly different means of accession E from the other ones within the sowing/ harvest date 

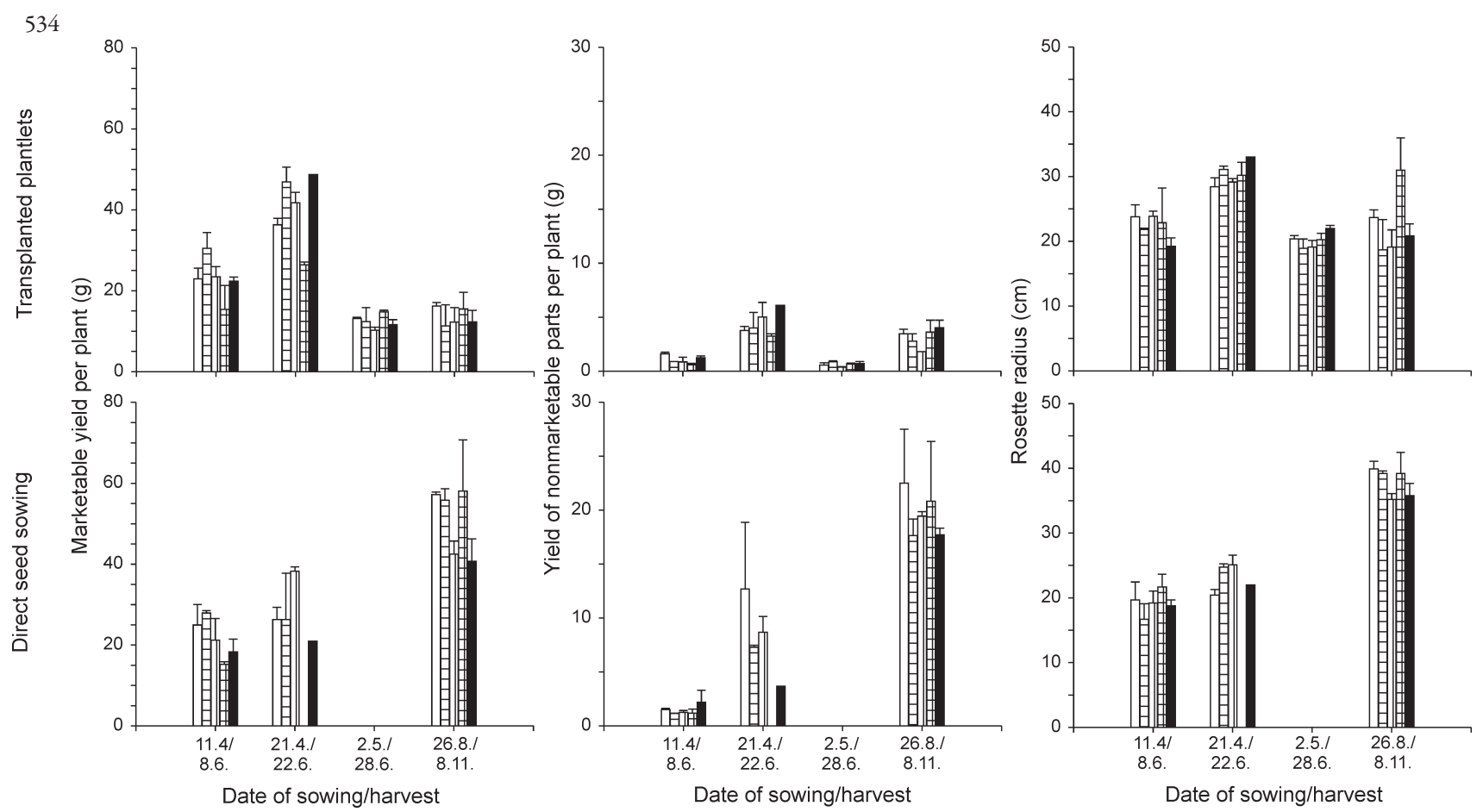

Fig. 3. Mean (+ 1 standard error) of marketable yield of leaves per plant, weight of nonmarketable parts per plant and rosette radius per variety (accession) (A, C, D, E, F from left to right) for various dates of sowing/harvest and cultivation technique in the 2011 experiment

Tab. 4. Effect of cultivation technique, variety and date of sowing on the marketable yield of leaves, weight of nonmarketable parts per plant and rosette radius of E. sativa in the years 2010 and 2011

\begin{tabular}{|c|c|c|c|c|c|c|c|}
\hline \multicolumn{2}{|l|}{2010} & \multicolumn{2}{|c|}{ Marketable yield of leaves per plant } & \multicolumn{2}{|c|}{$\begin{array}{c}\text { Weight of nonmarketable } \\
\text { parts per plant }\end{array}$} & \multicolumn{2}{|c|}{ Rosette radius } \\
\hline Source term & $\mathrm{DF}$ & $\mathrm{F}$ & $\mathrm{p}$ & $\mathrm{F}$ & $\mathrm{p}$ & $\mathrm{F}$ & $p$ \\
\hline $\begin{array}{l}\text { A: Cultivation } \\
\text { technique }\end{array}$ & 1 & 319.33 & $<0.001$ & 273.59 & $<0.001$ & 119.3 & $<0.001$ \\
\hline B: Variety & 4 & 1.97 & 0.137 & 1.62 & 0.209 & 6.74 & 0.001 \\
\hline$A \times B$ & 4 & 1.07 & 0.398 & 1.31 & 0.302 & 2.05 & 0.126 \\
\hline $\begin{array}{l}\text { C: Date of } \\
\text { sowing }\end{array}$ & 1 & 21.46 & $<0.001$ & 25.69 & $<0.001$ & 12.65 & 0.002 \\
\hline $\mathrm{A} \times \mathrm{C}$ & 1 & 43.73 & $<0.001$ & 11.04 & 0.003 & 26.52 & $<0.001$ \\
\hline $\mathrm{B} \times \mathrm{C}$ & 4 & 0.17 & 0.948 & 0.56 & 0.695 & 1.03 & 0.415 \\
\hline $\mathrm{A} \times \mathrm{B} \times \mathrm{C}$ & 4 & 1.12 & 0.373 & 0.80 & 0.537 & 1.62 & 0.208 \\
\hline \multicolumn{8}{|l|}{2011} \\
\hline Source term & $\mathrm{DF}$ & $\mathrm{F}$ & $\mathrm{p}$ & $\mathrm{F}$ & $\mathrm{p}$ & $\mathrm{F}$ & $\mathrm{p}$ \\
\hline $\begin{array}{l}\text { A: Cultivation } \\
\text { technique }\end{array}$ & 1 & 10.77 & 0.003 & 63.06 & $<0.001$ & 7 & 0.015 \\
\hline B: Variety & 4 & 4.61 & 0.006 & 1.31 & 0.289 & 0.33 & 0.804 \\
\hline$A \times B$ & 4 & 1.06 & 0.395 & 1.31 & 0.291 & 0.34 & 0.793 \\
\hline $\begin{array}{l}\text { C: Date of } \\
\text { sowing }\end{array}$ & 2 & 12.14 & $<0.001$ & 58.13 & $<0.001$ & 50.86 & $<0.001$ \\
\hline $\mathrm{A} \times \mathrm{C}$ & 2 & 77.22 & $<0.001$ & 43.02 & $<0.001$ & 102.87 & $<0.001$ \\
\hline $\mathrm{B} \times \mathrm{C}$ & 8 & 4.19 & $<0.001$ & 1.06 & 0.418 & 2.42 & 0.061 \\
\hline $\mathrm{A} \times \mathrm{B} \times \mathrm{C}$ & 8 & 1.13 & 0.374 & 0.91 & 0.521 & 1.2 & 0.343 \\
\hline
\end{tabular}

\section{Discussion}

Rocket is a fast growing and cool-season crop, well adapted to the Mediterranean area, but it can be success- fully cultivated throughout the world (Padulosi, 1995; Padulosi and Pignone, 1997). It can be cultivated also in temperate regions in Midwest of North America (Morales and Janick, 2002). As for as rocket cultivation in the 
Central Europe, Francke (2011) and Nurzyńska-Wierdak (2006) pointed out a possibility of rocket cultivation under open air conditions and in unheated greenhouse. Šimon and Strašil (1999), Moudrý and Strašil (1999) reported cultivation of rocket under open air conditions of the Czech Republic, however these trials were focussed on rocket growing as a unconventional crop for the vegetable oil production. Present study was undertaken to investigate the potential of $E$. sativa for cultivation as a leaf vegetable under the field conditions of the Czech Republic.

Plantlets of rocket varieties (accessions) emerged in both the greenhouse and in the field within 6-10 days. These results are consistent with the data cited by Bianco (1995). However, Francke (2011) reported emergence of $E$. sativa plants 12-16 days after sowing in plots without protective cover. Market demand requires healthy, green leaves harvested before shooting and flowering. As reported by Padulosi (1995) and Padulosi and Pignone (1997), longer days and high temperatures induce fast growth and flowering of rocket plants. That is why the term of sowing on the June $8^{\text {th }}$ in 2010 was not appropriate for the production of marketable leaf yield. Higher mean day temperatures (Tab. 2) caused early bolting and flowering. Thus the plants could not be evaluated due to the absence of fully developed leaf rosettes. Several leaves of these plants appeared to be rich in fibres and the taste was too bitter. In 2011, the same was true for the effect of late spring term on sowing on the May $2^{\text {nd }}$ in directly sown treatment and summer term of sowing ( $17^{\text {th }}$ August) in both cultivation treatments. Our trials confirmed that higher mean day temperatures in 2011 (average day temperatures in April, May and August were about $2^{\circ} \mathrm{C}$ higher in 2011 than those in 2010, Tab. 2) led to early bolting and flowering of plants without rosette formation. Therefore, the short-day growing with lower temperatures is favourable to obtain maximal leaf production of good-quality in temperate zones. The most appropriate sowing term under the warmer climatic conditions in the lower altitudes of the Czech Republic, with respect to quickness of bolting and subsequent flowering, seems to be the second half of April and late August for spring and autumn harvests, respectively.

There were found significant differences in marketable yield between plants raised from seed directly sown into the soil and transplanted plantlets in both years (Fig. 1). Plants cultivated from sown seed reached a marketable yield on average from 15 to $60 \mathrm{~g}$ per plant while transplanted plants produced on average from 10 to $49 \mathrm{~g}$ per plant. All these values are however apparently higher than approximately 8-12 g per plant reported by NurzyńskaWierdak $(2006,2009)$ from studies of yield parameters of rocket cultivated in pots in a glasshouse. For comparison with other available data on production of rocket, obtained data per unit area were recalculated (Tab. 5). It follows that the marketable yield reached in our trials is similar or even higher (depending on method of cultiva- tion, cultivar and date of harvest) than reported by Pimpini and Enzo (1997) for the Veneto region in Italy. They mentioned yields of around 16-18 $\mathrm{t} \times \mathrm{ha}^{-1}$, which is the average production per hectare in protected and open field areas. In this region the direct sowing technique is mostly used. In contrast, Varga et al. (2009) cultivated rocket in a greenhouse with a maximum yield of up to $5.14 \mathrm{~kg} \times \mathrm{m}^{-2}$ per one harvest that is fairly higher than yield obtained under the conditions of the Czech Republic.

Regarding the importance of the interaction between date of sowing and cultivation technique, plants from plantlets transplanted to the field at the end of April (spring term of sowing) had a substantially higher marketable yield and had larger rosette radius in comparison with plants from seed sowing treatment. Conversely, for the summer term of sowing, it was found that plants from seeds directly sown in the second half of August and in September showed unambiguously higher yield parameters. The lower sum of precipitation together with higher temperatures during September in both growing periods, when transplantation to the field was realised, seems to benefit the direct sowing technique. At that time, plants have already developed roots and possess an abundant root system adapted to open air conditions, in contrast to plantlets grown in a greenhouse subsequently transplanted to the field. In addition, as was mentioned above, the directly sown plants of the second sowing term on June $8^{\text {th }}$ in 2010 and the third sowing on May $2^{\text {nd }}$ in 2011, when the temperatures were rather high, bolted and flowered without rosette formation. In rocket culture, high temperatures seem to be a limiting factor for the production of green, tender leaves appropriate for human consumption.

Differences in environmental conditions between spring and summer also likely explain contrasting pattern of production of nonmarketable parts between cultivation techniques. While no significant differences in production of nonmarketable parts were found between two cultivation techniques in spring terms, plants produced from direct seed sowing produced significantly more nonmarketable parts than plants from plantlets in summer terms of sowing. Moreover, while nonmarketable parts composed less than $1 / 3$ of yield of marketable parts in the spring terms in both treatments, transplanted plants from summer terms produced up to $1 / 2$ of marketable parts and plants from seeds produced ca 1:1 nonmarketable to marketable parts yield.

The results showed that searching for the varieties with high marketable yield under the conditions of Central Europe is not an easy matter. Varieties showed no clear pattern of production of marketable parts that varied with year, date of sowing and cultivation technique. Taking into account two most productive varieties in each combination of term of sowing and cultivation technique (Figs. 2, 3 and Tab. 5), varieties $A$ and accession $E$ tended to be the most productive in the direct seed sowing treatment while variety $\mathrm{C}$ and accession $\mathrm{D}$ tended to be the most produc- 
536

tive in the plantlets treatment. Moreover, accession F was the least productive of marketable parts at all. Accession E also showed tendency to produce larger rosette radius in comparison with other varieties.

Before the 1990 s, rocket was usually collected in the wild and was not cultivated on a large scale or researched scientifically. At the end of the 1990s, The Rocket Genetic Resources Network was formed as a project of IPGRI (Bioversity International) which contributes to the conservation and utilization of rocket germplasm as well as to the extension of genetic diversity for future improvement of rocket (Padulosi, 1995; Padulosi and Pignone, 1997). The reasons are a very limited number of varieties suiting market demand and extensive harvests in the wild for market supply resulting in destruction of natural populations. The study pointed out a possibility of rocket cultivation under open air conditions of the warmer parts of the Czech Republic in order to supply the market with locally grown vegetable. From the varieties available in the Czech market seems to be the best the variety A from Semo Ltd., Smržice and varieties $\mathrm{C}$ and D from Seva-Seed Ltd., Valtice.

Tab. 5. Mean marketable yield of leaves $\left(\mathrm{kg} . \mathrm{m}^{-2}\right)$ of E. sativa varieties and accessions in the years 2010 and 2011 (DSS = direct seed sowing treatment, $\mathrm{TP}=$ transplanted plantlets)

\begin{tabular}{|c|c|c|c|c|c|c|c|}
\hline \multicolumn{8}{|c|}{ Date of sowing / harvest } \\
\hline & & 23.8.2010/ & 13.9.2010/ & $11.4 .2011 /$ & $21.4 .2011 /$ & $2.5 .2011 /$ & 26.8.2011/ \\
\hline & & 14.10 .2010 & 1.12 .2010 & 8.6 .2011 & 22.6.2011 & 28.6.2011 & 8.11 .2011 \\
\hline $\begin{array}{l}\text { Variety/ } \\
\text { Accession }\end{array}$ & \multicolumn{7}{|c|}{ Marketable yield of leaves $\left(\mathrm{kg} \cdot \mathrm{m}^{-2}\right)$} \\
\hline \multirow{2}{*}{ A } & DSS & 3.49 & 3.87 & 1.62 & 1.68 & - & 3.74 \\
\hline & $\mathrm{TP}$ & 1.62 & 0.76 & 1.99 & 3.16 & 1.14 & 1.41 \\
\hline \multirow{2}{*}{$\mathrm{C}$} & DSS & 2.19 & 2.70 & 1.82 & 1.66 & - & 3.65 \\
\hline & $\mathrm{TP}$ & 1.48 & 0.66 & 6.66 & 4.07 & 1.08 & 0.98 \\
\hline \multirow{2}{*}{$\mathrm{D}$} & DSS & 2.12 & 3.31 & 1.38 & 2.50 & - & 2.77 \\
\hline & $\mathrm{TP}$ & 1.63 & 4.44 & 2.04 & 3.61 & 0.89 & 1.06 \\
\hline \multirow{2}{*}{ E } & DSS & 3.68 & 3.94 & 1.00 & - & - & 3.79 \\
\hline & $\mathrm{TP}$ & 1.44 & 0.56 & 1.33 & 2.30 & 1.28 & 1.38 \\
\hline \multirow{2}{*}{$\mathrm{F}$} & DSS & 2.93 & 3.12 & 1.19 & 1.37 & - & 2.66 \\
\hline & $\mathrm{TP}$ & 1.29 & 0.64 & 1.94 & 4.24 & 1.01 & 1.07 \\
\hline
\end{tabular}

\section{Conclusions}

The present study has shown that rocket can be successfully cultivated under field conditions of the Czech Republic and can considerably enrich the diet of the modern Czech consumer. Our experiments: (i) have shown that in general it is possible to grow rocket under field conditions in the regions with an altitude about $200 \mathrm{~m}$ a. s. 1 ., on loam and sandy-loam soil, at temperatures between $10{ }^{\circ} \mathrm{C}$ and $25^{\circ} \mathrm{C}$ during the growing period, and using additional watering during dry periods; (ii) have demonstrated significant interaction between growing technique and date of sowing, i.e. plantlets treatment is preferable for spring term of sowing, while directly seed sowing is preferable for the summer term of sowing; (iii) proved that even the Czech rocket varieties have yields comparable with those of foreign varieties. At the same time, the obtained information can be applied as a background for future selection, production and industrial processing of rocket.

\section{Acknowledgements}

The research was supported by the Ministry of Agriculture of the Czech Republic, Project No. 0002700604. Project No. ED0007/01/01 from the Centre of the Region
Haná for Biotechnological and Agricultural Research and internal grant No. PrF 2013/03 from Palacký University in Olomouc are acknowledged.

\section{References}

Alqasoumi S, Al Howiriny T, Al Yahya M, Syed R (2009). Rocket "Eruca sativa": A salad herb with potential gastric anti ulcer activity. World J Gastroentero 15:1958-1965.

Bhandari DC, Chandel KPS (1997). Status of rocket germplasm in India: research accomplishments and priorities, p. 67-75. In: Padulosi S, Pignone D (Eds.). Rocket: A Mediterranean crop for the world. Report of a workshop 13-14 December 1996, Legnaro (Padova), Italy.

Bianco VV (1995). Rocket, an ancient underutilized vegetable crop and its potential. In: Padulosi S (Ed.). Rocket Genetic Resources Network. Report of the First Meeting, 13-15 November 1994, Lisbon, Portugal.

Bianco VV, Boari F (1997). Up-to-date developments on wild rocket cultivation, p. 41-49. In: Padulosi S, Pignone D (Eds.). Rocket: A Mediterranean crop for the world. Report of a workshop 13-14 December 1996, Legnaro (Padova), Italy.

Francke A (2011). The effect of flat covers on the quantity and 
quality of arugula yield. Acta Sci Pol-Hortoru 10:3-14.

Hertmuth J, Dotlačil L, Michalová A, Čejka L (2001). Productivity and diversity of agronomic characters in selected cultivars of eleven alternative crops. Czech J Genet Plant 37:93-102.

Mohamedien S (1995). Conservation and utilization of rocket in Mediterranean countries. Rocket cultivation in Egypt, p. 61-62. In: Padulosi S (Ed.). Rocket Genetic Resources Network. Report of the First Meeting, 13-15 November 1994, Lisbon, Portugal.

Morales M, Janick J (2002). Arugula: A promising specialty leaf vegetable, p. 418-423. In: Janick J, Whipkey A (Eds.). Trends in new crops and new uses. ASHS Press, Alexandria, VA.

Moudrý J, Strašil Z (1999). Pěstování alternativních plodin. Cultivation of alternative crops. $1^{\text {st }}$ Ed. Jihočeská univerzita, České Budějovice, 165 p.

Nuez F, Hernández Bermejo JE (1994). Neglected horticultural crops, p. 303-332. In: Hernándo Bermejo JE, León J (Eds.). Neglected Crops: 1492 from a different perspective. Plant Production and Protection Series 26. FAO, Rome, Italy.

Nurzyńska-Wierdak R (2006). The effect of nitrogen fertilization on yield and chemical composition of garden rocket (Eruca sativa Mill.) in autumn cultivation. Acta Sci PolHortoru 5:53-63.

Nurzyńska-Wierdak R (2009). Growth and yield of garden rocket (Eruca sativa Mill.) affected by nitrogen and potassium fertilization. Acta Sci Pol-Hortoru 8:23-33.

Nurzyńska-Wierdak R, Dzida K, Rożek E, Jarosz Z (2012a). Effects of nitrogen and potassium fertilization on growth, yield and chemical composition of garden rocket. Acta Sci Pol-Hortoru 11:289-300.

Nurzyńska-Wierdak R, Dzida K, Rożek E, Jarosz Z (2012b). The effect of nitrogen and potassium on N-NH4 and nNO3 accumulation and nutrient contents in rocket (Eruca sativa Mill.) leaves. Acta Sci Pol-Hortoru 11:211-221.

Padulosi S (Ed.) (1995). Rocket Genetic Resources Network. Report of the First Meeting, 13-15 November 1994, Lisbon, Portugal.
Padulosi S, Pignone D (Eds.) (1997). Rocket: A Mediterranean crop for the world. Report of a workshop 13-14 December 1996, Legnaro (Padova), Italy.

Pignone D, Gómez-Campo C (2011). Eruca, p. 149-160. In: Kole C (Ed). Wild crop relatives: genomic and breeding resources, oilseeds. Springer-Verlag, Berlin, Heidelberg, Germany.

Pimpini F, Enzo M (1997). Present status and prospects for rocket cultivation in the Veneto region, p. 51-66. In: Padulosi S, Pignone D (Eds.). Rocket: A Mediterranean crop for the world. Report of a workshop 13-14 December 1996, Legnaro (Padova), Italy.

Silva Dias JC (1997). Rocket in Portugal: botany, cultivation, uses and potential, p. 81-85. In: Padulosi S, Pignone D (Eds.). Rocket: A Mediterranean crop for the world. Report of a workshop 13-14 December 1996, Legnaro (Padova), Italy.

Šimon J, Strašil Z (1999). Perspektivy pěstování plodin pro nepotravinářské účely. Prospects for growing crops for nonfood purposes. ÚZPI, Praha, $50 \mathrm{p}$.

Tuzel Y (1995). Conservation and utilization of rocket in Mediterranean countries. Rocket growing in Turkey, p. 58-60. In: Padulosi S (Ed.). Rocket Genetic Resources Network. Report of the First Meeting, 13-15 November 1994, Lisbon, Portugal.

USDA, NRCS. 2012. The PLANTS Database (http://plants. usda.gov, visited on 26 September 2012). National Plant Data Team, Greensboro, NC 27401-4901 USA.

Varga J, Apahidean AS, Lujerdean A, Bunea A (2009). Study of some agrotechnological characteristics of rocket (Eruca sativa Mill). Bull UASVM. Horticulture 66:472-474.

Zar JH (1996). Biostatistical analysis. $4^{\text {th }}$ Ed. Prentice Hall, New Jersey. 663 p. 